NBER WORKING PAPER SERIES

\title{
CHARITABLE BEQUESTS AND TAXES \\ ON INHERITANCES AND ESTATES: \\ AGGREGATE EVIDENCE FROM ACROSS STATES AND TIME
}

\author{
Jon Bakija \\ William Gale \\ Joel Slemrod \\ Working Paper 9661 \\ http://www.nber.org/papers/w9661 \\ NATIONAL BUREAU OF ECONOMIC RESEARCH \\ 1050 Massachusetts Avenue \\ Cambridge, MA 02138 \\ April 2003
}

Prepared for the American Economic Association Meetings, January 3, 2003 Session: Estate Taxation. The views expressed herein are those of the authors and not necessarily those of the National Bureau of Economic Research.

(C2003 by Jon Bakija, William Gale and Joel Slemrod. All rights reserved. Short sections of text not to exceed two paragraphs, may be quoted without explicit permission provided that full credit including Cnotice, is given to the source. 
Charitable Bequests and Taxes on Inheritance and Estates:

Aggregate Evidence from across States and Time

Jon Bakija, William Gale, and Joel Slemrod

NBER Working Paper No. 9661

April 2003

JEL No. H0, H2

\section{$\underline{\text { ABSTRACT }}$}

One recurring issue in the debate over the estate tax is its impact on the non-profit sector. With the top marginal rate of federal estate tax currently at 49 percent, abolishing the tax would approximately double the price of a charitable bequest relative to an ordinary bequest for the wealthiest estates. It would also, however, raise the after-tax wealth of decedents, so the ultimate impact of any particular policy change depends in part on the relative sizes of the price and wealth elasticities.

This paper estimates the impact of taxes on charitable bequests using an econometric framework that exploits the fact that federal and state tax rates on estates and inheritances have changed over time in different ways across states and real wealth levels. The effect of federal and state inheritance and estate taxes on charitable bequests is estimated using pooled cross-sectional data spanning several decades, based on aggregated information from federal estate tax returns. Under several different specifications, we find evidence that the incentives for charitable giving present in state and federal estate and inheritance taxes have a strong positive effect on charitable bequests. Our estimates that rely on differences in the time path of state and federal tax rates across groups provide a more credible source of identification than the previous literature of a large and significant price elasticity of charitable bequests.

Jon Bakija

Department of Economics

Fernald House

Williams College

Williamstown, MA 01267

jbakija@williams.edu
William Gale

Brookings Institution

1775 Massachusetts Ave., NW

Washington, DC 20036

wgale@brookings.edu
Joel Slemrod

University of Michigan

Business School

701 Tappan St., A2120

Ann Arbor, MI 48109-1234 and NBER

jslemrod@umich.edu 


\title{
Charitable Bequests and Taxes on Inheritances and Estates: Aggregate Evidence from across States and Time
}

\author{
BY JON M. BAKIJA, WILLIAM G. GALE, AND JOEL B. SLEMROD*
}

After years of neglect, the estate and gift tax recently became the center of a heated policy debate, culminating with provisions in the tax cut enacted in June 2001 that will reduce the estate tax gradually, repeal it in 2010 , and then reinstate it in its pre-2001 form at the beginning of 2011. This patchwork treatment virtually guarantees that estate tax rules will be revisited soon.

One recurring issue in the estate tax debate is the impact of reform on the non-profit sector. The federal estate tax has allowed a deduction for charitable bequests since 1918 (Barry Johnson et al, 2001). With the top marginal rate of federal estate tax currently at 49 percent, abolishing the tax would approximately double the price of a charitable bequest relative to an ordinary bequest for the wealthiest estates. It would also, however, presumably raise the aftertax wealth of decedents, so the ultimate impact of any particular policy change depends in part on the relative sizes of the price and wealth elasticities.

Cross-sectional studies typically find that decedents with larger estates and therefore higher marginal federal estate tax rates make larger charitable bequests (see David Joulfaian, 2000, for an up-to-date example and literature review). The interpretation of this result is unclear, though, because the federal tax rate is an increasing, nonlinear function of estate size, and the true functional form of the relationship between wealth and charity is uncertain. If wealth has a non-linear effect on charitable bequests that is not accurately captured in the estimated functional form, the price elasticity estimate may suffer from omitted variable bias (Daniel Feenberg, 1987). Wojciech Kopczuk and Joel Slemrod (2003) use aggregate annual 
time-series analysis to show that several different summary measures of the marginal federal estate tax rate have a small but positive influence on aggregate reported charitable bequests. But it is difficult to adequately distinguish the impact of changing tax rates from other, possibly unobserved time-varying influences and trends in aggregate time-series analysis.

This paper contains early results from a research program designed to estimate the impact of taxes on charitable bequests using an econometric framework that addresses several problems that plague prior research. We exploit the fact that federal and state tax rates on estates and inheritances have changed over time in different ways across states and real wealth levels. The effect of federal and state inheritance and estate taxes on charitable bequests is estimated using pooled cross-sectional data spanning several decades, based on aggregated information from federal estate tax returns. Under several different specifications, we find evidence of a strong incentive effect of estate and inheritance taxes on charitable bequests.

\section{Data and Federal-State Tax Calculator}

We use a data set provided by the Statistics of Income Division of the Internal Revenue Service (IRS) and drawn from a confidential IRS data set of federal estate tax returns. The underlying data set contains a nearly 100 percent sample of federal estate tax returns for deaths through 1945, and a stratified sample of returns for selected postwar years, with sampling weights (i.e., weights based on the inverse of the sampling probability) available. The tables provided to us aggregate returns into cells based on year / state / wealth level / marital status combinations, and include the sample-weighted average charitable bequests and wealth measures for each cell.

For this study, we focus on returns filed by a second-to-die spouse. ${ }^{1}$ In 1998 , these widows and widowers accounted for $44 \%$ of federal estate returns filed, and $63 \%$ of the 
aggregate value of charitable bequest deductions (Kopczuk and Slemrod, 2003, Table 7).

Our analysis includes all years for which the IRS conducted a study that drew a substantial sample of decedents, and for which information on state of residence and marital status are available. This leaves us with 39 years: 1924 through 1945, 1969, 1976, 1982, and 1985 through 1998. Data are arranged into cells based on five wealth categories, expressed in 1996 dollars: $\$ 400,000$ to $\$ 750,000 ; \$ 750,000$ to $\$ 1.25$ million; $\$ 1.25$ million to $\$ 2$ million; $\$ 2$ million to $\$ 5$ million; and $\$ 5$ million and above. To maintain comparable compositions of decedents in each cell over time, we omitted cells for which the real federal estate tax filing threshold was above the minimum bound for the cell. After removing cells with no decedents in the sample (or in many cases, in the population) we have 6,615 cells.

The two main explanatory variables of interest are disposable wealth at death, and the tax price of charitable bequests. Both require accurate measures of combined federal and state tax rates, which are not directly available in the data set. To address this, we have developed a tax calculator that computes combined federal-state inheritance and estate taxes for an individual in any state and any year. The calculator appropriately accounts for factors such as the deductibility of federal taxes from many state taxes, the limited non-refundable federal credit for death taxes paid to a state, and whether charity was exempt from the state tax.

Pre-tax wealth is defined as the gross estate reported on the federal estate tax return, minus debts and mortgages, plus certain components of wealth that were excluded from the gross estate. $^{2}$ This is close to a comprehensive measure of net worth at death that is largely consistent across time for our sample of widows and widowers. Returns are sorted into cells based on pretax wealth. "Disposable wealth" is wealth minus the combined federal and state inheritance and estate tax liability. 
We define the tax price of charitable bequests $\left(\mathrm{P}^{\mathrm{e}}\right)$ as the opportunity cost of an increase in charitable bequests in terms of ordinary bequests foregone. This is equal to one minus the marginal estate and inheritance tax rate. We compute this marginal rate as (negative) the change in combined federal and state tax liability caused by a $\$ 10,000$ increase in the amount of charitable bequest, divided by $\$ 10,000$. State inheritance taxes typically imposed different rates and exemptions depending on how the estate was divided up among different types of heirs. The data do not provide information on the recipients of bequests, so we assume that the net estate (after bequests to charity) is divided equally between two adult children.

The time-series path of state tax rates differed substantially across states during our sample period, and also typically differed across wealth classes within a state. Marginal federal rates at all wealth levels considered in our study increased dramatically over time, starting at or below 10 percent in 1924, and rising to the $40-60$ percent range by the late 1990s. Importantly for our purposes, the time-series path of the federal marginal tax rate differs across wealth levels. For instance, the marginal rate faced by the typical return in our top wealth class has came down after hitting a peak of 70 percent during the 1970 s, at the same time that rates at lower real wealth levels continued to climb slowly.

\section{Econometric Specification}

Following William Randolph (1995), Joulfaian (2000), and others, we model the demand for charitable giving using a Deaton-Muellbauer (1980) expenditure share equation. We estimate:

(1) $\mathrm{P}^{\mathrm{e}}{ }_{\mathrm{it}} \mathrm{G}_{\mathrm{it}} / \mathrm{W}_{\mathrm{it}}=\alpha+\mathbf{X}_{\mathrm{it}} \beta_{0}+\beta_{1} \ln \left(\mathrm{P}_{\mathrm{it}}^{\mathrm{e}}\right)+\beta_{2}\left(\ln \mathrm{W}_{\mathrm{it}}\right)+\varepsilon_{\mathrm{it}}$, 
where $i$ indexes state-wealth class cells, and $t$ indexes years. $\mathrm{P}_{\text {it }}^{\mathrm{e}}$ is the price of charitable bequest relative to a bequest to heirs, based on current law applying at the date of death, calculated at the sample-weighted mean taxable estate in the cell. ${ }^{3} \quad \mathrm{G}_{\mathrm{it}}$ is the sample-weighted cell-mean charitable bequest. $\mathrm{W}_{\mathrm{it}}$ is disposable wealth at death, calculated as sample-weighted mean pretax wealth for the cell minus the tax liability that applies at the cell-mean taxable estate. Both G and W are measured in 1996 dollars. $\mathbf{X}_{\mathbf{i t}}$ is a vector of control variables, consisting of sets of dummy variables for wealth class, year, and state, depending on the specification.

We use instrumental variables to address the familiar problem that $\mathrm{P}^{\mathrm{e}}$ and $\mathrm{W}$ are endogenously related to charitable bequests, since a larger donation to charity reduces tax liability and can push a decedent into a lower marginal tax bracket. Our approach to constructing the instrumental variables will also be an important part of our strategy for addressing certain forms of omitted variable bias, which will be discussed further in the next section. As an instrument for $\ln \left(\mathrm{P}^{\mathrm{e}}\right)$, we construct a measure of $\ln \left(\mathrm{P}^{\mathrm{e}}\right)$ based on the marginal tax rate at the midpoint of the wealth category of which each cell is a member. This midpoint is constant in real terms over time. Similarly, to construct an instrument for $\ln (\mathrm{W})$, we calculate $\mathrm{ATR}_{\mathrm{M}}$, the average tax rate (defined as tax liability divided by pre-tax wealth) calculated at the midpoint wealth in the cell. The instrument is $\log$ of $\left[\right.$ pre-tax wealth $\left.\times\left(1-\mathrm{ATR}_{\mathrm{M}}\right)\right]$. In both cases, for the top wealth category, in place of a midpoint, we use the median level of wealth among the pooled observations from that category, which is $\$ 12.7$ million in 1996 dollars.

Our model is estimated by weighted linear two-stage least squares, where the weights are based on the number of returns sampled by the IRS that underlie each cell. ${ }^{4}$ The proportion of cells with zero charitable bequests, weighted in this fashion, is 3.3 percent, so censoring is present but is unlikely to be a large problem. ${ }^{5}$ We compute standard errors that are robust to 
arbitrary autocorrelation within each state / wealth category combination, and robust to arbitrary heteroskedasticity across such combinations.

Elasticities are of particular interest in this application. In the Deaton-Muellbauer functional form, elasticities vary across individuals, depending on the expenditure share of charity. The elasticity of charitable bequest with respect to price for an individual (cell) is $\eta_{\text {Pit }}=$ $\beta_{1}\left(\mathrm{~W}_{\mathrm{it}} / \mathrm{P}^{\mathrm{e}}{ }_{\mathrm{it}} \mathrm{G}_{\mathrm{it}}\right)-1$; the wealth elasticity of charity is $\eta_{\mathrm{Wit}}=\beta_{2}\left(\mathrm{~W}_{\mathrm{it}} / \mathrm{P}^{\mathrm{e}}{ }_{\mathrm{it}} \mathrm{G}_{\mathrm{it}}\right)+1$. When $\beta_{1}$ or $\beta_{2}$ equal zero, the elasticity is -1 or 1 , respectively. Thus, a significance test of the coefficient value is really a significance test for whether the elasticity is one in absolute value. For ease of interpretation, we present the elasticity of aggregate charitable bequests with respect to a uniform percentage change in price or disposable wealth for all observations. For price, this is $\left[\Sigma_{\text {it }}\left(\mathrm{G}_{\mathrm{it}} \eta_{\text {Pit }}\right)\right] /\left(\Sigma_{\mathrm{it}} \mathrm{G}_{\mathrm{it}}\right)$; for wealth, it is $\left[\Sigma_{\mathrm{it}}\left(\mathrm{G}_{\mathrm{it}} \eta_{\mathrm{Wit}}\right)\right] /\left(\Sigma_{\mathrm{it}} \mathrm{G}_{\mathrm{it}}\right)$.

\section{Results}

Table 1 presents results from estimating four different versions of equation (1). Each successive specification adds a set of dummy variables that removes certain forms of identification from the independent variation left in $\mathrm{W}$ and especially $\mathrm{P}^{\mathrm{e}}$, thereby removing potential biases caused by omitted influences that may be correlated with those sources of identification.

Specification (a) includes no control variables in $\mathbf{X}$, thus allowing all forms of variation -aggregate time-series, cross-sectional differences across wealth levels, etc. -- to identify price and wealth effects. This results in a price elasticity of -1.62 and a wealth elasticity of 1.32 , both very precisely estimated. The most comparable estimate in the recent literature comes from Joulfaian (2000, p. 755), who finds a price elasticity of -0.74 and wealth elasticity of 1.54 using a roughly similar specification, but on a cross-section of 1992 unmarried decedents. 
In specification (b) we add a set of wealth class dummy variables to (a). This not only allows for a more flexible and arbitrary non-linear relationship between wealth and charity, but in conjunction with the cell midpoint-based instrument set, it purges the independent variation in price of all variation caused by its non-linear relationship with wealth. The remaining independent variation in price comes from state tax rates, and from changes over time in federal tax rates at fixed real wealth levels caused by statutory changes and bracket creep. This eliminates any bias to the price coefficient that might otherwise be caused by omitted non-linear functions of real wealth. The elasticity estimates remain robust to addressing this potential bias, as they are similar to those in (a).

In specification (c), we add year dummies to (b), which removes aggregate time-series variation from the independent variation in price and wealth, eliminating the potential for omitted variable bias caused by time-varying aggregate influences that affected everyone's expenditure share of charity in a similar way. This causes the most notable change across our specifications, as the price elasticity increases from -1.69 to -1.91 and its standard error triples from 0.10 to 0.33 . The increased standard error is not surprising, since aggregate time-series variation in federal marginal tax rates, which is removed as a source of identification by specification (c), is large relative to the other available sources of variation in price.

In specification (d), which is the most robust to omitted variable bias, we add state dummies to (c), to control for any time-invariant omitted characteristics of states. The identification of the price effect in this last specification arises entirely from differences in the time path of tax rates across wealth classes, across states, and across wealth classes within states. The price elasticity estimate is -2.14 with a standard error of 0.33 , and the wealth elasticity estimate is 1.55 with a standard error of 0.10 . After addressing many potential sources of bias, 
the main result is preserved: the incentive effect of estate and inheritance taxes on charitable bequests is large and significant. If anything, it appears that the potential sources of omitted variable bias addressed here had been biasing the price elasticity downward in absolute value.

Among the widows and widowers present in our 1998 sample, eliminating estate and inheritance taxes would have raised the price of charitable bequests by 77 percent, on average, while raising disposable wealth by an average of only 24 percent. The difference arises because of the progressivity of these taxes, which means that marginal tax rates are much higher than average tax rates. As a result, to a rough approximation, total repeal will cause charitable bequests to decline among this population unless the wealth elasticity is more than three times as large as the price elasticity (in absolute value), which is far from what we estimate. Our estimates therefore point towards a decline in charitable bequests in response to the abolishing estate and inheritance taxes.

\section{Conclusions}

Using pooled cross sections of aggregated estate tax return data spanning much of the $20^{\text {th }}$ century, we find evidence that the incentives for charitable giving present in state and federal estate and inheritance taxes have a strong effect on charitable bequests. Our estimates that rely on differences in the time path of state and federal tax rates across groups provide a more credible source of identification than the previous literature of a large and significant price elasticity of charitable bequests. 


\section{REFERENCES}

Deaton, Angus S. and Muellbauer, John. "An Almost Ideal Demand System." American Economic Review, 1980. 70(3), June, pp. 323-26.

Feenberg, Daniel. "Are Tax Price Models Really Identified: The Case of Charitable Giving." National Tax Journal, 1987. 40(4), December, pp. 629-33.

Johnson, Barry W., Jacob M. Mikow, and Martha Britton Eller. "Elements of Federal Estate Taxation" in William G. Gale, James R. Hines Jr., and Joel Slemrod, eds., Rethinking Estate and Gift Taxation. Washington, DC: Brookings Institution Press, 2001, pp. 65-107.

Joulfaian, David. "Estate Taxes and Charitable Bequests by the Wealthy." National Tax Journal, 2000. 53(3), Part 2, September, pp. 743-63.

Kopczuk, Wojciech and Joel Slemrod. "Tax Impacts on Wealth Accumulation and Transfers of the Rich," in Alicia Munnell and Annika Sunden, eds., Death and Dollars: The Role of Gifts and Bequests in America. Washington, DC: Brookings Institution Press, 2003, pp. 21357.

Randolph, William C. "Dynamic Income, Progressive Taxes, and the Timing of Charitable Contributions.” Journal of Political Economy, 1995, 103(4), August, pp. 709-38. 


\section{TABLE 1 -- EFFECTS OF PRICE AND DISPOSABLE WEALTH ON CHARITABLE BEQUESTS}

\begin{tabular}{lcccc}
\hline \hline $\begin{array}{l}\text { Dependent } \\
\text { variable: } \mathrm{P}^{\mathrm{e}} \mathrm{G} / \mathrm{W}\end{array}$ & \multicolumn{2}{c}{ Coefficient } & \multicolumn{2}{c}{ Elasticity* } \\
& $\ln \left(\mathrm{P}^{\mathrm{e}}\right)$ & $\ln (\mathrm{W})$ & Price & $\begin{array}{c}\text { Disposable } \\
\text { wealth }\end{array}$ \\
\hline (a) No controls & -0.050 & 0.026 & -1.617 & 1.316 \\
& $(0.006)$ & $(0.001)$ & $(0.072)$ & $(0.018)$ \\
$\begin{array}{l}\text { (b) Add wealth class } \\
\quad \text { dummies to (a) }\end{array}$ & -0.056 & 0.040 & -1.690 & 1.490 \\
$\begin{array}{l}\text { (c) Add year } \\
\quad \text { dummies to (b) }\end{array}$ & $-0.008)$ & $(0.008)$ & $(0.102)$ & $(0.095)$ \\
$\begin{array}{l}\text { (d) Add state } \\
\quad \text { dummies to (c) }\end{array}$ & $-0.026)$ & $(0.043$ & -1.913 & 1.527 \\
& $(0.027)$ & $(0.008)$ & $(0.325)$ & $(0.093)$ \\
\end{tabular}

Notes: Robust standard errors are in parentheses. Estimated by weighted 2SLS.

* Elasticity of aggregate charitable bequests with respect to a uniform percentage change in price or disposable wealth for all individuals in sample. 


\section{FOOTNOTES}

* Bakija: Department of Economics, Williams College, and The Brookings Institution, Washington DC 20036; Gale: The Brookings Institution; Slemrod: University of Michigan, Ann Arbor, MI 48109. We thank Manijeh Azmoodeh, Chris Lyddy, and Edward Major for painstaking research assistance, Barry Johnson and Wojciech Kopczuk for help with the data, David Joulfaian for insightful comments, and The Nathan Cummings Foundation for financial support.

1. Joulfaian (2000) and Kopczuk and Slemrod (2003) discuss some of the difficulties involved in specifying the incentives to give to charity for the first-to-die spouse, and in using the spousal deduction as a source of price variation.

2. Until 1942 , up to $\$ 40,000$ of life insurance owned by the decedent could be excluded from the gross estate. Starting in 1977, the difference between the market value of certain farm and small business property and its "special use" value in that capacity could be excluded. Each of these exclusions is added back in to our measure of wealth.

3. The "taxable estate" we use to calculate the "actual" tax liabilities and marginal rates is the gross estate for federal tax purposes, less debts, mortgages, and charitable bequests, where each of these variables represents the sample-weighted mean value for the cell.

4. Weighted regression is necessary for consistent estimation of standard errors and efficiency when the data represent means of the values for multiple individual observations. The variance of these means will be inversely proportional to the number of individuals contributing to the calculation of the mean for each cell, causing heteroskedasticity.

5. We also tried estimating each equation with a Tobit model (results not shown), and found that the elasticity estimates were very similar. 